\title{
Influence of Salt Stress on Seed Germination and Agro- morphological Traits in Chickpea (Cicer arietinum L.)
}

Munqez J.Y. Shtaya, Heba Al-Fares, Tawfiq Qubbaj, Hassan Abu-Qaoud, Faisal Shraim

10.18805/LR-633

\begin{abstract}
Background: The experiment was conducted at the Faculty of Agriculture and Veterinary Medicine, An-Najah National University, Palestine under growth chamber and greenhouse conditions.

Methods: To study the effect of $\mathrm{NaCl}$ on germination, fifty seeds in each treatment for each cultivar were germinated on a filter paper in petri dishes moistened with the different $\mathrm{NaCl}$ concentration levels $(0.0,50$ and $100 \mathrm{mM})$. To study the effect of $\mathrm{NaCl}$ on plant growth and productivity, 2 seeds per variety were grown in 10 liter pots filled with peat moss-sand. Pots were irrigated with the different $\mathrm{NaCl}$ levels.

Result: The tested chickpea cultivars showed different tolerance levels in response to $\mathrm{NaCl}$ stress levels. $\mathrm{NaCl}$ reduced final germination percentage (FGP) and germination index (GI). The highest plant height was obtained by Einalbeda $(38.63 \mathrm{~cm})$ in the control group, while the lowest one was found in Arij $(28.25 \mathrm{~cm})$ under $100 \mathrm{mM} \mathrm{NaCl}$. NaCl did not affect root/shoot ratio in all genotypes. Reduction in fresh weight ranged between 25.6 and $74.2 \%$ under 50 and $100 \mathrm{mM} \mathrm{NaCl}$.
\end{abstract}

Key words: Chickpea, Germination index, $\mathrm{NaCl}$, Root/shoot ratio, Salinity.

\section{INTRODUCTION}

Soil salinity negatively affects plant growth and development. Salinity is estimated to affect around one-third of all irrigated land in the world, the number is increasing (Singla and Garg, 2005; Shahid et al., 2018). The middle east is considered as the world's most salt-affected area (Hossain, 2019). The elevation of soil soluble salts will lead to specific ion toxicity and ionic imbalances (Munns, 2003). Therefore, drastic reduction in crop plant growth and productivity may occur as a result of the accumulative salinity in arable land and even plant death may occur (Rout and Shaw, 2001).

Improving crop tolerance to salinity is one of the ecofriendly and sustainable measures that can be used to reduce the negative effects of salinity on plants. As a result, there has recently been an increase in interest in researching and selecting salinity-tolerant genotypes using both conventional and nontraditional selection and breeding techniques (Ceritoğlu et al., 2020).

Chickpea (Cicer arietinum L.) is classified as one of the main legumes and in many countries, it is considered an important source of protein and is widely used as fodder crop or even as green manure (Geethanjali et al., 2018). Chickpea seeds are rich in amino acids, vitamins, protein

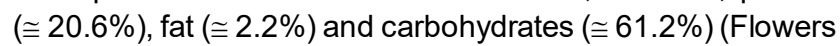
et al., 2010; Ceritoğlu et al., 2020; Jha et al., 2021). Chickpea is classified as a highly sensitive crop to salinity (Hossain et al., 2015). It is reported that salinity could decrease growth, grain yield and other yield components in chickpea (Sohrabi et al., 2008; Kandil et al., 2012; Pushpavalli et al., 2020).

Therefore, the identification of new sources of salinity tolerant genotypes is of great realistic importance. Chickpea is native to arid areas; consequently, it may have an
Department of Plant Production and Protection, Faculty of Agriculture and Veterinary Medicine, An-Najah National University, Nablus P.O. Box 707, Palestine.

Corresponding Author: Tawfiq Qubbaj, Department of Plant Production and Protection, Faculty of Agriculture and Veterinary Medicine, An-Najah National University, Nablus P.O. Box 707, Palestine. Email: tqubbaj@najah.edu

How to cite this article: Shtaya, M.J.Y., Al-Fares, H., Qubbaj, T., Abu-Qaoud, H. and Shraim, F. (2021). Influence of Salt Stress on Seed Germination and Agro-morphological Traits in Chickpea (Cicer arietinum L.). Legume Research. 44(12): 1455-1459. DOI:10.18805/LR-633.

Submitted: 31-05-2021 Accepted: 06-08-2021 Online: 06-09-2021

important level of adaptability to different environmental stresses, including salinity (Krouma, 2009). Therefore, it provides a valuable source of more resistant cultivars with minimal yield loss when grown in saline conditions and it could be a viable solution to the salinity problem (Rao et al., 2002). The study was planned with an aim to compare the responses of Kabuli and Desi chickpea cultivars to salinity in terms of growth and yield.

\section{MATERIALS AND METHODS}

\section{Plant material and experimental design}

Three chickpea varieties were used in the study, including two desi landraces (Einalbeda and Arij) and Kabuli variety (Hadas). All varieties were obtained from the Palestinian national agricultural research center. Experiments were implemented under controlled conditions in the growth chamber and under greenhouse conditions during the 2020 -2021 growing season at the Faculty of Agriculture and 
Influence of Salt Stress on Seed Germination and Agro-morphological Traits in Chickpea (Cicer arietinum L.)

Veterinary Medicine, An-Najah National University, Palestine. Both experiments were set in factorial arrangement in a complete randomized design (CRD) with four replications.

\section{Effect of salinity on seed germination}

To study the effect of $\mathrm{NaCl}$ on germination, fifty seeds per treatment per cultivar were used. Seeds of uniform size, were surface sterilized in $3 \%(\mathrm{v} / \mathrm{v})$ of bleach (sodium hypochloride $5.25 \%$ ) solution for $10 \mathrm{~min}$, rinsed three times in distilled water and then were germinated on a filter paper in $12 \mathrm{~cm}$ square petri-dishes. The filter paper was moistened with the solution of the three different $\mathrm{NaCl}$ levels $(0,50$ and $100 \mathrm{mM}$ ). The petri-dishes were kept at $22^{\circ} \mathrm{C}$ (day/night temperatures) and under darkness for germination. Germination was evaluated after 8 days. Seeds were considered as having germinated when the radicle protruded to a length of $2 \mathrm{~mm}$ and the following parameters were calculated:

1. Final germination percentage (FGP): FGP was calculated using the following equation:

$$
\text { FGP }=\frac{\text { Number of germinated seed }}{\text { Total number of seed tested }} \times 100
$$

2. Germination index (GI): GI was calculated according to the following equation:

$$
\mathrm{GI}=\frac{\% \text { Germination each treatment }}{\% \text { Germination in the control }} \times 100
$$

\section{Effect of salinity on seedling growth and production}

Two pre-germinated seeds per variety were grown in a 10 liter pot filled with a mixture of peat moss-sand $(1: 2, \mathrm{v} / \mathrm{v})$. Pots were irrigated with fresh water for two weeks and then the following levels $(0,50,75$ and $100 \mathrm{mM})$ of $\mathrm{NaCl}$ were applied (for the control treatment, $0 \mathrm{mM} \mathrm{NaCl}$, fresh water was added). Pots were irrigated every second day by adding $250 \mathrm{ml}$ of the corresponding $\mathrm{NaCl}$ concentration. Seventy days after sowing, the experiments were terminated and the following plants' parameters were collected and analyzed:

1. Plant height $(\mathrm{cm})$ : Measured from the soil surface to the top of the plant.

2. Root and plant fresh weight (g).

3. Root and plant dry weight $(\mathrm{g})$ : Dried in an electric oven for $72 \mathrm{~h}$ at $70^{\circ} \mathrm{C}$.

4. Plant height reduction (PHR): It was calculated using the following equation:

$\mathrm{PHR}(\%)=\frac{\mathrm{PH} \text { at control }-\mathrm{PH} \text { at the saline condition }}{\mathrm{PH} \text { at the saline condition }} \times 100$

5. Plant fresh weight reduction (PFWR): It was calculated using the following equation:

PFWR $(\%)=$

$\frac{\text { Plant weight at control }-\begin{array}{c}\text { Plant weight at the } \\ \text { saline condition }\end{array}}{\text { Plant weight at the saline condition }} \times 100$
6. Root/shoot $(R / S)$ ratio: The $R / S$ ratio was calculated as:

$$
\text { Root } / \text { shoot ratio }=\frac{\text { Roots dry weight }}{\text { Shoot dry weight }}
$$

\section{Data analysis}

ANOVA analysis was conducted for the different tested parameters, followed by the Bonferroni mean separation test using MINITAB (18) software.

\section{RESULTS AND DISCUSSION}

In the present study, the tested chickpea cultivars showed different tolerance levels in response to $\mathrm{NaCl}$ stress levels. The inhibitory effects of salinity on morphological traits were observed on the plants at the beginning of the third week after $\mathrm{NaCl}$ application. However, the early negative effect of $\mathrm{NaCl}$ was observed during seed germination, where $\mathrm{NaCl}$ reduced FGP and $\mathrm{GI}$.

\section{Final germination percentage (FGP)}

The final germination percentage (FGP) showed significant differences between varieties and $\mathrm{NaCl}$ treatments with a significant interaction between the two factors (Table 1). In comparison, all tested varieties completed the FGP in the control treatment $(100 \%$ of the seeds germinated). The same germination reduction pattern was reported by Farooq et al. (2017) and Dadaşoğlu et al. (2020) on other chickpeas varieties and the $100 \mathrm{mM} \mathrm{NaCl}$ concentration found to be the critical threshold for germination in chickpea (Dadaşoğlu et al. 2020).

Similar results were also reported in rice (Islam and Karim, 2010) and chickpea (Özaktan et al., 2018; Ceritoğlu et al. 2020). Although 50 and $100 \mathrm{mM} \mathrm{NaCl}$ did not significantly affect the final germination percentage and germination index of Arij (Small seed variety) (93.33 and $83.33 \%$ respectively). Einalbeda was the most affected variety where FGP was significantly reduced at 50 and 100 $\mathrm{mM} \mathrm{NaCl}$ (80 and $73.33 \%$ respectively). Hadas (big seed variety) germination was not affected under $50 \mathrm{mM} \mathrm{NaCl}$ $(86.67 \%)$ while FGP was significantly reduced under 100 $\mathrm{mM} \mathrm{NaCl}(76.67 \%)$. Al-Mutawa (2003) reported that the rate and percentage of seed germination of chickpea were significantly reduced by increasing salinity levels and the magnitude of the reduction varied among genotypes Kaya et al. (2008) reported that small seed chickpea varieties can germinate in a shorter time than large seed varieties under saline conditions. The results showed that increasing $\mathrm{NaCl}$ concentration caused crucial impacts not only on germination rate but also on the agronomic traits; these findings agree with the results reported by Ceritoğlu et al. (2020). Flowers et al. (2010) stated that chickpea is a plant affected by salinity, where the most tolerant genotypes can't survive for a long time at $100 \mathrm{mM} \mathrm{NaCl}$ solution while the susceptible genotypes will die in just $25 \mathrm{mM} \mathrm{NaCl}$ solution.

\section{Plant height}

After 70 days of growth under different $\mathrm{NaCl}$ concentrations (50, 75 and $100 \mathrm{mM})$, the tested chickpeas varieties showed some differences in terms of growth parameters. The plant 
height showed significant differences between varieties and $\mathrm{NaCl}$ treatments with a significant interaction (Table 2). These findings agreed with the results reported by Ceritoğlu et al. (2020) and Yousef et al. (2020). The highest plant height was obtained by Einalbeda $(38.63 \mathrm{~cm})$ in the control group, while the lowest one was found in Arij $(28.25 \mathrm{~cm})$ under $100 \mathrm{mM} \mathrm{NaCl}$. The mean plant height of cultivars ranged between 31.67 and $34.42 \mathrm{~cm}$. The reduction rates in plant height depending on $\mathrm{NaCl}$ treatments are given in Fig 1. Plant height reduction was relatively higher under $100 \mathrm{mM}$ than the lower $\mathrm{NaCl}$ concentrations. Welfare et al. (2002) reported that high salinity has negative effects on plant height. Arij showed a higher tolerance rate regarding plant height under $50 \mathrm{mM}$ and $75 \mathrm{mM}$, respectively, while it was the most sensitive under $100 \mathrm{mM} \mathrm{NaCl}$. It was reported that the growth rate was higher in tolerant chickpea genotypes compared with susceptible ones under salinity stress (Kafi et al. 2011).

\section{Root/shoot ratio}

To test the effect of different $\mathrm{NaCl}$ levels on plant growth, the shoot/root ratio was calculated (Table 2). Obtained results show that $\mathrm{NaCl}$ did not affect root/shoot ratio in all genotypes, indicating that roots and shoots are in the same range of sensitivity to $\mathrm{NaCl}$ stress. A higher root shoot length ratio indicated that the selection of stress tolerance might help improve grain yield (Mazhar et al. 2020; Masood et al. 2020).

\section{Plant fresh and dry weight}

There were significant differences in plant fresh and dry weight between varieties and $\mathrm{NaCl}$ treatments. Significant interaction also affected the fresh and dry weights of the plants (Table 3). These findings are consistent with those stated by Ceritoğlu et al. (2020). According to Welfare et al. (2002), Sohrabi et al. (2008) and Hossain et al. (2015), high salinity has a negative impact on shoot weight. Fig 2 showed the reduction percentage in plant fresh weight. The reduction was varied among the three varieties, Hadas was the most influential one. Reduction in fresh weight ranged between $25.6 \%$ and $74.2 \%$ under 50 and $100 \mathrm{mM} \mathrm{NaCl}$, respectively (the average reduction was $54.3 \%$ ). The least affected variety was Arij; the reduction in fresh weight ranged between $4.9 \%$ and $27.2 \%$ under 50 and $100 \mathrm{mM} \mathrm{NaCl}$, respectively affected by $\mathrm{NaCl}$. Similar results were reported in chickpea and pea (Yousef et al., 2020; (the average reduction was $12.9 \%)$. Einalbeda showed the lowest reduction in plant fresh

Table 1: The effect of $\mathrm{NaCl}$ on final germination percentage and germination index of three chickpea cultivars.

\begin{tabular}{|c|c|c|c|c|c|c|}
\hline \multirow{2}{*}{ Variety } & \multicolumn{3}{|c|}{ Final germination percentage (FGP) } & \multicolumn{3}{|c|}{ Germination index $(\mathrm{Gl})$} \\
\hline & Control & $50 \mathrm{mM}$ & $100 \mathrm{mM}$ & Control & $50 \mathrm{mM}$ & $100 \mathrm{mM}$ \\
\hline Einalbeda & $100.00^{\mathrm{a}}$ & $80.00^{\mathrm{bc}}$ & $73.33^{c}$ & $1.00^{\mathrm{a}}$ & $0.80^{\mathrm{bc}}$ & $0.73^{c}$ \\
\hline Arij & $100.00^{\mathrm{a}}$ & $93.33^{\mathrm{ab}}$ & $83.33^{\mathrm{abc}}$ & $1.00^{\mathrm{a}}$ & $0.93^{\mathrm{ab}}$ & $0.83^{\mathrm{abc}}$ \\
\hline Hadas & $100.00^{a}$ & $86.67^{a b c}$ & $76.67^{b c}$ & $1.00^{\mathrm{b}}$ & $0.87^{a b c}$ & $0.77^{b c}$ \\
\hline
\end{tabular}

Numbers share the same letter(s) are not significantly differ (Bonferroni test, $\mathrm{P}=.05$ ).

Table 2: The effect of different levels of $\mathrm{NaCl}$ on plant height $(\mathrm{cm})$ and on shoot/root ratio of three chickpea cultivars.

\begin{tabular}{lcccccccc}
\hline \multirow{2}{*}{ Variety } & \multicolumn{4}{c}{ Plant height $(\mathrm{cm})$} & \multicolumn{3}{c}{ Shoot/root ratio } \\
\cline { 2 - 8 } & Control & $50 \mathrm{mM}$ & $75 \mathrm{mM}$ & $100 \mathrm{mM}$ & Control & $50 \mathrm{mM}$ & $75 \mathrm{mM}$ & $100 \mathrm{mM}$ \\
\hline Einalbeda & $38.63^{\mathrm{a}}$ & $35.50^{\mathrm{abc}}$ & $36.38^{\mathrm{ab}}$ & $36.25^{\mathrm{ab}}$ & $0.34^{\mathrm{ab}}$ & $0.27^{\mathrm{ab}}$ & $0.24^{\mathrm{b}}$ & $0.50^{\mathrm{ab}}$ \\
Arij & $31.63^{\mathrm{abc}}$ & $32.25^{\mathrm{abc}}$ & $31.63^{\mathrm{abc}}$ & $28.25^{\mathrm{c}}$ & $0.25^{\mathrm{b}}$ & $0.26^{\mathrm{ab}}$ & $0.25^{\mathrm{ab}}$ & $0.34^{\mathrm{ab}}$ \\
Hadas & $33.00^{\mathrm{abc}}$ & $31.63^{\mathrm{abc}}$ & $30.38^{\mathrm{bc}}$ & $30.50^{\mathrm{bc}}$ & $0.52^{\mathrm{ab}}$ & $0.42^{\mathrm{ab}}$ & $0.54^{\mathrm{a}}$ & $0.45^{\mathrm{ab}}$ \\
\hline
\end{tabular}

Numbers share the same letter(s) are not significantly differ (Bonferroni test, $\mathrm{P}=.05$ ).

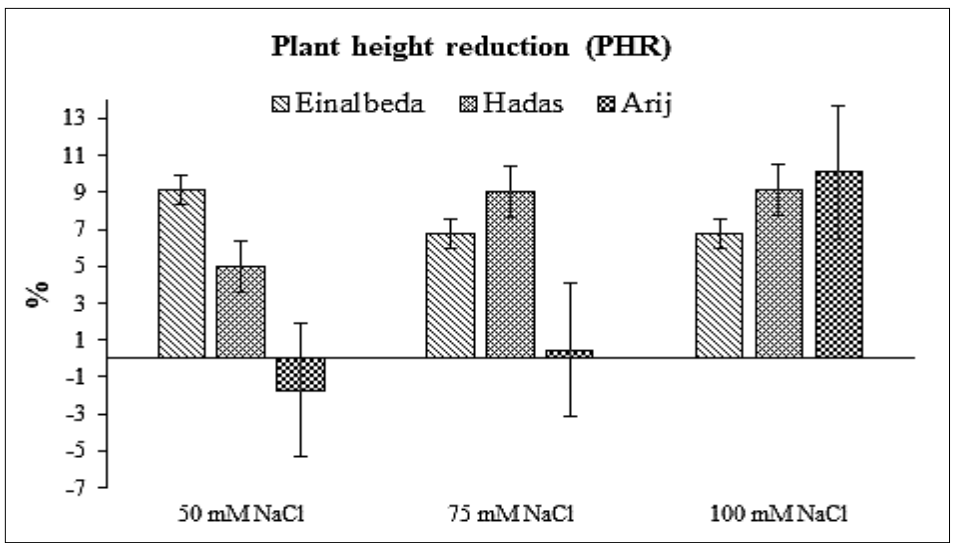

Fig 1: Plant height reduction percentage of three chickpea cultivars depending on $\mathrm{NaCl}$ treatments. 


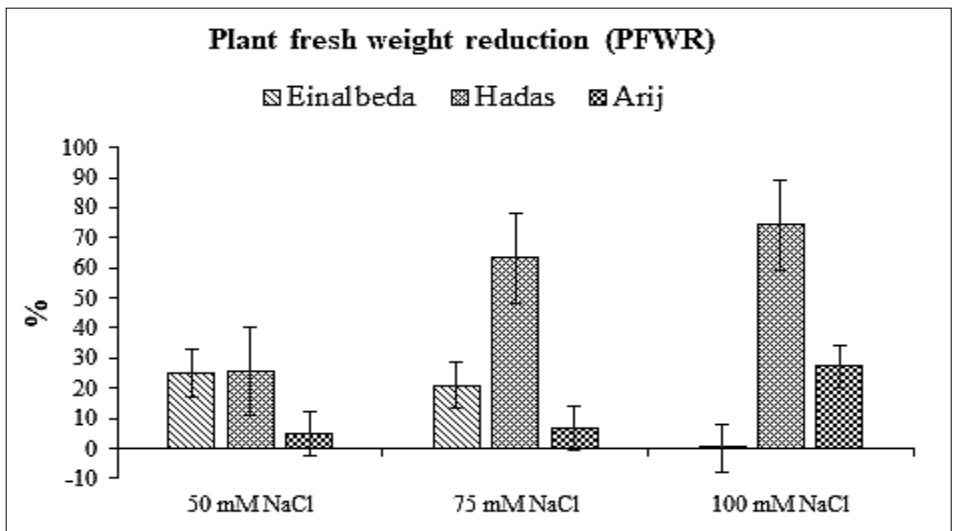

Fig 2: Plant fresh weight reduction percentage of three chickpea cultivars depending on $\mathrm{NaCl}$ treatments.

Table 3: The effect of different levels of $\mathrm{NaCl}$ on Plant fresh and dry weight of three chickpea cultivars.

\begin{tabular}{lllllllll}
\hline \multirow{2}{*}{ Variety } & \multicolumn{4}{c}{ Plant fresh weight $(\mathrm{g})$} \\
\cline { 2 - 8 } & Control & $50 \mathrm{mM}$ & $75 \mathrm{mM}$ & $100 \mathrm{mM}$ & Control & $50 \mathrm{mM}$ & $75 \mathrm{mM}$ & $100 \mathrm{mM}$ \\
\hline Einalbeda & $22.93^{\mathrm{ab}}$ & $15.61^{\text {cd }}$ & $16.15^{\mathrm{bcd}}$ & $19.52^{\mathrm{abc}}$ & $8.68^{\mathrm{a}}$ & $7.04^{\mathrm{abc}}$ & $7.45^{\mathrm{abc}}$ & $7.35^{\mathrm{abc}}$ \\
Arij & $15.20^{\text {cd }}$ & $14.49^{\text {cd }}$ & $14.24^{\text {cd }}$ & $11.95^{\mathrm{d}}$ & $7.04^{\mathrm{abc}}$ & $6.69^{\mathrm{abc}}$ & $6.53^{\mathrm{abc}}$ & $5.65^{\mathrm{c}}$ \\
Hadas & $24.10^{\mathrm{a}}$ & $19.20^{\mathrm{abc}}$ & $14.77^{\text {cd }}$ & $13.84^{\text {cd }}$ & $8.29^{\mathrm{ab}}$ & $7.87^{\mathrm{ab}}$ & $6.09^{\mathrm{bc}}$ & $5.94^{\mathrm{bc}}$ \\
\hline
\end{tabular}

Numbers share the same letter(s) are not significantly differ (Bonferroni test, $\mathrm{P}=.05$ ).

Table 4: The effect of different levels of $\mathrm{NaCl}$ on root fresh and dry weight of three chickpea cultivars.

\begin{tabular}{lcccccccc}
\hline \multirow{2}{*}{ Variety } & \multicolumn{3}{c}{ Root fresh weight $(\mathrm{g})$} & \multicolumn{4}{c}{ Root dry weight $(\mathrm{g})$} \\
\cline { 2 - 9 } & Control & $50 \mathrm{mM}$ & $75 \mathrm{mM}$ & $100 \mathrm{mM}$ & Control & $50 \mathrm{mM}$ & $75 \mathrm{mM}$ & $100 \mathrm{mM}$ \\
\hline Einalbeda & $8.81^{\mathrm{bc}}$ & $4.27^{\mathrm{cd}}$ & $3.90^{\mathrm{d}}$ & $10.05^{\mathrm{ab}}$ & $0.54^{\mathrm{b}}$ & $0.40^{\mathrm{b}}$ & $0.36^{\mathrm{b}}$ & $0.37^{\mathrm{b}}$ \\
Arij & $3.73^{\mathrm{d}}$ & $3.74^{\mathrm{d}}$ & $3.51^{\mathrm{d}}$ & $4.16^{\mathrm{cd}}$ & $0.42^{\mathrm{b}}$ & $0.33^{\mathrm{b}}$ & $0.35^{\mathrm{b}}$ & $0.30^{\mathrm{b}}$ \\
Hadas & $14.77^{\mathrm{a}}$ & $7.92^{\mathrm{bcd}}$ & $7.81^{\mathrm{bcd}}$ & $6.82^{\mathrm{bcd}}$ & $0.96^{\mathrm{a}}$ & $0.60^{\mathrm{b}}$ & $0.58^{\mathrm{b}}$ & $0.44^{\mathrm{b}}$ \\
\hline
\end{tabular}

Numbers share the same letter $(\mathrm{s})$ are not significantly differ (Bonferroni test, $\mathrm{P}=.05$ ).

weight under $100 \mathrm{mM}$ (0.1\% reduction) (Fig 2). Plant dry weight was significantly Dadaşoğlu et al. (2020) Einalbeda showed the highest dry weight over $\mathrm{NaCl}$ treatments without significant difference from the control (Table 3).

\section{Root fresh and dry weight}

The root fresh weight showed significant differences between varieties and $\mathrm{NaCl}$ treatments, whereas no significant difference was observed in root dry weight between the tested varieties (Table 4). This is in agreement with the results reported in chickpea (Abdiev et al., 2019) and forage pea (Acikbas et al., 2021). Despite the salinity, Hadas showed the highest root fresh and dry weights (14.77 and $0.96 \mathrm{~g}$, respectively) compared to Einalbeda and Arij.

\section{CONCLUSION}

According to the present results, varieties and $\mathrm{NaCl}$ showed significant effects on studied traits and the interaction between varieties and $\mathrm{NaCl}$ treatments significantly affected the majority of the studied traits. The results showed that increasing $\mathrm{NaCl}$ concentration caused crucial impacts not only on germination rate but also on the agronomic traits. Plant height reduction was relatively higher under $100 \mathrm{mM}$ than the lower $\mathrm{NaCl}$ concentrations. Obtained results show that $\mathrm{NaCl}$ did not affect root/shoot ratio in all genotypes, indicating that roots and shoots are in the same range of sensitivity to $\mathrm{NaCl}$ stress.

\section{REFERENCES}

Abdiev, A., Khaitovb, B., Toderichd, K. and Park, K.W. (2019). Growth, nutrient uptake and yield parameters of chickpea (Cicer arietinum L.) enhance by rhizobium and azotobacter inoculations in saline soil. Journal of Plant Nutrition. 42: 2703-2714.

Acikbas, S., Ozyazici, M.A. and Bektas, H. (2021). The effect of salinity on root architecture in forage pea (Pisum sativum ssp. arvense L.). Legume Research. 44: 407-412.

Al-Mutawa, M.M. (2003). Effect of salinity on germination and seedling growth of chickpea (Cicer arietinum L.) genotypes. International Journal of Agriculture and Biology. 5: 226-229.

Ceritoğlu, M., Erman, M. and Yildiz, F. (2020). Effect of salinity on germination and some agro-morphological traits in chickpea seedlings. ISPEC Journal of Agricultural Sciences. 4: 82-96.

Dadaşoğlu, E., Ekinci, M. and Yıldırım, E. (2020). Effects of salt stress on seed germination of chickpea (Cicer arietinum L.) and pea (Pisum sativum L.). Atatürk University Journal of Agricultural Faculty. 51: 53-62. 
Influence of Salt Stress on Seed Germination and Agro-morphological Traits in Chickpea (Cicer arietinum L.)

Farooq, M., Gogoi, N., Hussain, M., Barthakur, S., Paul, S., Bharadwaj, N., Migdadi, H.M., Alghamdi, S.S. and Siddique, K.H.M. (2017). Effects, tolerance mechanisms and management of salt stress in grain legumes. Plant Physiology and Biochemistry. 118: 199-217.

Flowers, T.J., Gaur, P.M., Gowda, C.L.L., Krishnamurthy, L., Samineni, S., Siddique, K.H.M., Turner, N.C., Vadez, V., Varshney, R.K. and Colmer, T.D. (2010). Salt sensitivity in chickpea. Plant, Cell and Environment. 33: 490-509.

Geethanjali, D., Sudha Rani, M. and Jayalakshmi, V. (2018). Genetic diversity analysis in chickpea (Cicer arietinum L.) grown under rainfed and irrigated conditions for quality and yield attributing traits. Indian Journal of Agricultural Research. 52: 691-695.

Hossain, S. (2019). Present scenario of global salt affected soils, its management and importance of salinity research. International Research Journal of Biological Science. 1: 1-3.

Hossain, M.I., Mannan, M.A. and Karim, M.A. (2015). Salicylic acid and gibberelic acid ameliorates the adverse effects of salinity on chickpea. Bangladesh Agronomy Journal. 18: 81-88.

Islam, M.M. and Karim, M.A. (2010). Evaluation of rice (Oryza sativa L.) genotypes at germination and early seedling stage for their tolerance to salinity. Agriculturists. 8: 57-65.

Jha, U.C., Kole, P.C. and Singh, N.P. (2021). QTL mapping for heat stress tolerance in chickpea (Cicer arietinum L.). Legume Research- An International Journal. 44: 382-387.

Kafi, M., Bagheri, A., Nabati, J., Mehrjerdi, M. and Masomi, A. (2011). Effect of salinity on some physiological variables of 11 chickpea genotypes under hydroponic conditions. Journal of Science and Technology of Greenhouse Culture Soilless Culture Research Center. 1: 55-70.

Kandil, A.A., Sharief, A.E. and Ahmed,S.R.H. (2012). Germination and seedling growth of some chickpea cultivars (Cicer arietinum L.) under salinity stress. Journal of Basic and Applied Sciences. 8: 561-571.

Kaya, M., Kaya, G., Kaya, M.D., Atak, M., Saglam, S., Khawar, K.M. and Ciftci, C.Y. (2008). Interaction between seed size and $\mathrm{NaCl}$ on germination and early seedling growth of some Turkish cultivars of chickpea (Cicer arietinum L.). Journal of Zhejiang University Science B. 9: 371.

Krouma, A. (2009). Physiological and nutritional responses of chickpea (Cicer arietinum L.) to salinity. Turkish Journal of Agriculture and Forestry. 33: 503-512.
Masood, M., Ahsan, M., Sadaqat, H.A. and Awan, F. (2020). Screening of maize (Zea mays L.) inbred lines under water deficit conditions. Biological and Clinical Sciences Research Journal. 2020, p.e007.

Mazhar, T., Ali, Q. and Malik, M.S.R.A. (2020). Effects of salt and drought stress on growth traits of Zea mays seedlings. Life Science Journal. 17: 48-54.

Munns, R. (2003). Comparative physiology of salt and water stress. Plant Cell and Environment. 25: 239-250.

Özaktan, H., Çiftçi, C.Y., Kaya, M.D., Uzun, S., Uzun, O. and Akdogan, G. (2018). Chloride salts inhibit emergence and seedling growth of chickpea rather than germination. Legume Research. 41: 60-66.

Pushpavalli, R., Berger, J.D., Turner, N.C., Siddique, K.H.M., Colmer, T.D. and Vadez, V. (2020). Cross-tolerance for drought, heat and salinity stresses in chickpea (Cicer arietinum L.). Journal of Agronomy and Crop Science. 206: 405-419.

Rao, D.L.N., Giller, K.E., Yeo, A.R. and Flowers, T.J. (2002). The effects of salinity and sodicity upon nodulation and nitrogen fixation in chickpea (Cicer arietinum). Annals of Botany. 89: 563-570.

Rout, N.P. and Shaw, B.P. (2001). Salt tolerance in aquatic macrophytes: Ionic relation and interaction. Biologia Plantarum. 55: 91-95.

Shahid, S.A., Zaman, M. and Heng, L. (2018). Soil Salinity: Historical Perspectives and a World Overview of the Problem. In: Guideline for Salinity Assessment, Mitigation and Adaptation using Nuclear and Related Techniques. Springer, Cham.

Sohrabi, Y., Heidari, G. and Esmailpoor, B. (2008). Effect of salinity on growth and yield of Desi and Kabuli chickpea cultivars. Pakistan Journal of Biological Sciences. 11: 664-667.

Singla, R. and Garg, N. (2005). Influence of salinity on growth and yield attributes in chickpea cultivars. Turkish Journal of Agriculture and Forestry. 29: 231-235.

Welfare, K., Yeo, A.R. and Flowers, T.J. (2002). Effects of salinity and ozone, individually and in combination, on the growth and ion contents of two chickpeas (Cicer arietinum L.) varieties. Environmental Pollution. 120: 397-403.

Yousef, F., Shafique, F., Ali, Q. and Malik, A. (2020). Effects of salt stress on the growth traits of chickpea (Cicer arietinum L.) and pea (Pisum sativum L.) seedlings. Biological and Clinical Sciences Research Journal. 2020: e029. https:// doi.org/10.47264/bcsrj0101029. 